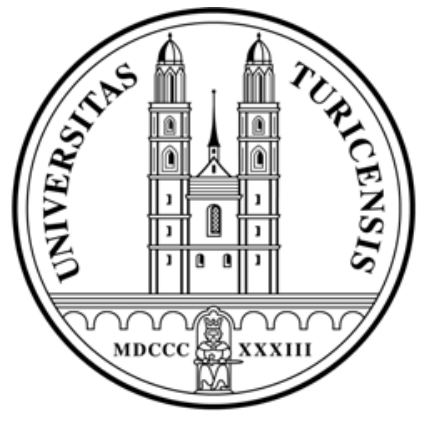

Institute for Empirical Research in Economics

University of Zurich

Working Paper Series

ISSN 1424-0459

Working Paper No. 385

The Risk Premium on the Euro Area Market

Portfolio:

The Role of Real Estate

Thomas Nitschka

August 2008 


\title{
The Risk Premium on the Euro Area Market Portfolio: The Role of Real Estate
}

\author{
Thomas Nitschka ${ }^{1}$ \\ Institute for Empirical Research in Economics, University of Zurich
}

\begin{abstract}
Incomplete consumption risk sharing implies that the market risk premium is high in times of lack of risk sharing and vice versa. In the time period from 1980 to 2007, this implication of incomplete consumption risk sharing for the market price of risk is not mirrored in excess returns on stocks but in returns on real estate both in the Euro Area and in the U.S. This finding thus casts doubt on the common practice to approximate the market return by a stock index return in empirical tests of the Sharpe-Lintner capital asset pricing model. However, cross-sectional asset pricing tests suggest that there are fundamental differences between the Euro Area and the U.S. in this respect. The return on real estate does not add any explanatory power for domestic or foreign asset returns in excess of a stock index return in the U.S. The opposite reasoning applies to the Euro Area. Finally, this paper shows that the distinction between rather global and country-specific pricing factors does not seem to be important for the pricing of excess returns on foreign currencies.
\end{abstract}

JEL: G10, G15

Keywords: CAPM, market risk premium, real estate return, return predictability, foreign currency returns

\footnotetext{
${ }^{1}$ E-mail: thomas.nitschka@iew.uzh.ch , Postal address: Chair of International Trade and Finance, Institute for Empirical Research in Economics, University of Zurich, Zurichbergstrasse 14, 8032 Zurich.

This research is part of the URPP Macro-Finance of the University of Zurich and has been conducted during my stay at the Monetary Policy Stance Division of the ECB. I am grateful to Mika Tujula and Bernhard Winkler for comments and for providing me with the Euro Area data sets used in this paper. Furthermore, I substantially benefited from comments and remarks by Mathias Hoffmann, Kjetil Støresletten and participants in an ECBMSN seminar and the $1^{\text {st }}$ URRP conference on Macro-Finance at the University of Zurich. In addition, I gratefully acknowledge that Kenneth French makes his data on value and growth stock portfolios publicly available. The views expressed in this paper do not necessarily reflect the view of the ECB or the Euro system. Any errors are entirely mine.
} 


\section{Introduction}

Real estate plays the dominant role in Euro Area households' balance sheets. On average, housing accounts for roughly 60 percent of households' asset wealth in the Euro Area in the period from the first quarter of 1980 to the first quarter of 2007 as is shown in figure (1). Norman et al. (2002) show that participation in stock markets is much less widespread in the core European countries than in the U.S. in contrast to participation in housing markets. In addition, funding of housing in the Euro Area countries is typically less financial market based than in the U.S. Securitisation of mortgages is widespread in the U.S. but negligible in the Euro Area (Tsatsaronis and Zhu (2004)). But despite these important institutional differences it is still common to neglect returns on real estate when the risk premium on the market portfolio of the Sharpe (1964), Lintner (1965), Black (1972) capital asset pricing model (CAPM) is approximated. ${ }^{2}$ This paper provides evidence that casts this practice into doubt for the Euro Area.

I assess the implications of incomplete consumption risk sharing for the risk premium on the Euro Area market portfolio following Lustig and van Nieuwerburgh (2005, 2006a,b). In the Lustig and van Nieuwerburgh framework, a currently high level of uninsured consumption risk should be associated with an expected increase in the market price of risk. In the time period from the first quarter of 1980 to the first quarter of 2007, lack of consumption risk sharing reflects high expected returns on real estate and low expected returns on a stock index thus suggesting that the return on real estate may be a better proxy for the Euro Area market return than the respective stock index return. However, this finding is not special for the Euro Area but qualitatively similar in U.S. data. This observation motivates the use of the return on real estate in addition to a stock index return when approximating the market portfolio return

\footnotetext{
${ }^{2}$ However, Jagannathan and Wang (1996) show that returns on human capital constitute an important component of the market portfolio risk premium.
} 
in empirical tests of the CAPM. Confronting the U.S. CAPM with the 25 book-to-market and size sorted Fama-French stock portfolios, I find the return on residential real estate to be neither helpful in pricing the cross-section of U.S. value and growth stock portfolio returns nor lowering the pricing errors compared with a CAPM version that features only the stock index return as market return proxy. This picture is different for the Euro Area. Here, the return on real estate is the only factor that helps to price Euro Area value and growth portfolio returns and the CAPM version taking account of real estate delivers the lowest pricing errors. Stambaugh (1982) emphasizes that the importance of components of the market portfolio such as real estate might differ across asset classes tested with the CAPM. Considering excess returns on foreign currencies, the distinction between stock and real estate returns could be particularly important. Stock market indexes of developed economies worldwide tend to comove which seems to mirror that national stock markets contain a substantial common component (see e.g. Nitschka (2007) and the literature surveyed therein). Real estate price indexes are arguably less prone to global, common shocks as home owners build their houses where they live. Hence, a real estate return should reflect rather country-specific than global risks. The opposite reasoning seems to apply to stock returns.

Hence, I confront U.S. and Euro Area CAPM versions that take into account the return on real estate with excess returns on foreign currency portfolios. The main results are easily summarized. From the U.S. perspective, the return on real estate does not help to explain the cross-section of foreign currency returns. If there is any explanatory power, then it is embodied in the stock market return. In the sample period under study, sensitivity of the foreign currency returns to the stock index return seems to explain their cross-sectional differences. However, the estimated risk price is by far too large to be in line with basic asset pricing theory thus corroborating Lustig et al. (2008) for a similar sample period. The same pricing exercise for the Euro Area corroborates the impression left by the stock return pricing exercises. A CAPM specification that features the return on real estate in the market return 
proxy delivers the lowest pricing errors. The return on real estate does not only help to price foreign currency returns but is significantly priced. This risk price, however, is also too far away from its theoretically sound value.

Taken together the main results of this paper suggest that the return on real estate does not add any information about systematic sources of risk in excess of a stock index return in the U.S. thus corroborating Stambaugh (1982). This finding holds even though the empirical evidence based on the Lustig and van Nieuwerburgh (2005) framework leaves the impression of a prominent role for real estate in tests of the CAPM. However, empirical tests of the Euro Area CAPM that neglect returns on real estate do not seem to appropriately proxy the market return. Irrespective of the type of test assets, Euro Area CAPM versions that take real estate into account perform best in terms of pricing errors. In addition, given the presence of each other the return on real estate helps to price the cross-section of asset returns while the stock return does not. Finally, this paper shows that the distinction between rather global or country-specific pricing factors, i.e. stock index return vs. real estate return, does not seem to be important for the pricing of foreign currency returns

The remainder of the paper is organized as follows. Section two discusses implications of incomplete consumption risk sharing for the risk premium on the market portfolio and assesses empirically the role of real estate in this context for both the Euro Area and the U.S. Section three provides details on the cross-sectional tests of CAPM versions with or without consideration of the real estate return when challenged with excess returns on stock and foreign currency portfolios. Finally, section four concludes.

\section{Incomplete consumption risk sharing and time series predictability of the market risk premium}

The basic idea of the consumption risk sharing literature is that consumers desire to insulate their consumption stream from idiosyncratic income shocks. However, consumption risk 
sharing is incomplete both within and across countries (Asdrubali et al. (1996), Sørensen and Yosha (1998)) even though risk sharing, i.e. isolating consumption from idiosyncratic income shocks, seems to have increased internationally in recent years (see e.g. Artis and Hoffmann (2007)).

One way to buffer idiosyncratic income shocks is to borrow and lend. This credit channel seems to be particularly important for households. However, households' access to credit markets varies over the business cycle (e.g. Gertler and Gilchrist (1994)). This observation is the point of departure of Lustig and van Nieuwerburgh (2005, 2006,a,b). They assess the implications of undiversified, idiosyncratic risk on the risk premium on asset markets. Lustig and van Nieuwerburgh (2005) model an economy in which households face common and idiosyncratic income shocks. Idiosyncratic income shocks can be smoothed through borrowing and lending. Loans are only granted on the basis of collateral. The more collateral available in this economy, the higher the number of households that are able to insure their idiosyncratic income risks. In Lustig and van Nieuwerburgh (2005, 2006a,b) the ratio of an economy's collateral wealth relative to wealth that is not accepted as collateral serves as a proxy for the tightness of credit constraints faced by households. Aggregate shocks, measured by this collateral to non-collateral ratio, directly affect the distribution of consumption across households. In times of relative scarcity of collateral assets more households are bound by credit constraints. Hence the dispersion in consumption growth rates at the household and regional level increases (Lustig and van Nieuwerburgh (2006a)). In addition, households will demand higher risk premia when collateral wealth is relatively low because their ability to insure idiosyncratic consumption risk is limited (Lustig and van Nieuwerburgh (2006b)). Empirically, real estate seems to be the ideal candidate as measure of collateral wealth. Since it is difficult to borrow only against human capital, human wealth is regarded as non-collateral wealth. Lustig and van Nieuwerburgh (2005) use after-tax labour income as defined by Lettau and Ludvigson (2001) to proxy for human wealth. This approach is valid under the 
assumption that labour income represents the dividend paid from human capital (Campbell (1996), Jagannathan and Wang (1996)). Lustig and van Nieuwerburgh (2005) find the housing-income ratio to be cointegrated around a time trend. Short-run fluctuations of the housing-income ratio should reflect the temporary tightening or relaxation of households' credit constraints and are closely related to consumption dispersion across households and regions. Hence, as predicted by the model, the temporary variation in the housing-income ratio predicts expected risk premia on the market portfolio approximated by the excess return on a broad U.S. stock market index in annual data for the time period from 1926 to 2002.

The next subsections assess the statistical properties of the euro area housing-income ratio and the implications for the Euro Area market risk premium in the time series.

\subsection{Housing wealth and income in the Euro Area}

To compute a Euro Area version of the housing-income ratio, I use housing wealth data compiled by the ECB and first published in the ECB monthly bulletin December 2006. Euro Area housing wealth is defined as the current market value of residential dwellings plus land owned by households. Quarterly housing wealth estimates are obtained from Euro Area data on housing capital stock and underlying value of land which are available for $80 \%$ of the Euro Area in terms of GDP coverage. The ECB applies a three step procedure to estimate Euro Area housing wealth from the capital stock and land data to obtain a final estimate that takes account of price changes of the capital stock of housing. I deliberately refer the reader to Box 5 of the ECB monthly bulletin December 2006 for full details of the estimation procedure.

Since after-tax labour income, the proxy of non-collateral wealth in the U.S., is not readily available for the Euro Area, I follow Hamburg et al. (2007) and employ disposable income of Euro Area households as proxy for the dividend on human wealth. Housing wealth and disposable income are graciously provided to me by the ECB. 
Both of the time series are integrated of order one, I(1). Results of unit root tests are not reported but available upon request. Lustig and van Nieuwerburgh (2005) show that the U.S. housing-income ratio is stationary around a deterministic time trend, i.e. housing and income are cointegrated around a time trend. Table 1 presents details of the Johansen cointegration test with regard to the logarithmic Euro Area housing-income ratio. In the test I allow for a deterministic time trend and two lags in the vector autoregressive representation of the two variables as suggested by standard information criteria. The test results strongly support the view that the two variables, housing and income, are cointegrated. Both of the test statistics suggest one cointegration relation among housing and income at the 99 percent confidence level.

Therefore, a vector error correction representation of the form

$$
\boldsymbol{\Gamma}(\boldsymbol{L})\left(\begin{array}{c}
\Delta h_{t} \\
\Delta i_{t}
\end{array}\right)=\boldsymbol{\alpha}\left[h_{t-1}+\gamma_{1} i_{t-1}+\gamma_{2} \text { timetrend }+\eta\right]+\boldsymbol{\varepsilon}_{t}
$$

must exist (Engle and Granger (1987)) where $h_{t}$ denotes the natural logarithm of real, p.c. housing wealth, $i_{t}$ represents the natural logarithm of real, p.c. disposable income. Bold uppercase letters highlight matrices, bold lower-case letters represent vectors. The vector of cointegration coefficients, $\boldsymbol{\beta}=\left[1,-\gamma_{1},-\gamma_{2}\right]^{\prime}$, describes the long-run relationship of housing, income and the time trend if the coefficient on housing is normalized to unity. Temporary deviations from this long-term relationship reflect variation in the tightness of households' credit constraints in the Lustig and van Nieuwerburgh (2005) framework.

The estimation of the cointegration vector via dynamic ordinary least squares (Stock and Watson (1993)) delivers $\hat{\boldsymbol{\beta}}=\left[\begin{array}{lll}1 & -\underset{(-3.48)}{1.43} i & \underset{(-2.89)}{0.00} \text { timetrend }\end{array}\right]^{\prime}$ if the cointegration coefficient 
of housing is normalized to unity. ${ }^{3}$ Temporary fluctuations in the housing-income ratio, henceforth abbreviated $h i_{t}$, are thus governed by

$$
h i_{t}=h_{t}-1.43 i_{t}-0.00 \text { timetrend }+\eta_{t}
$$

Lustig and van Nieuwerburgh (2005) emphasize that the cointegration vector should obey $\boldsymbol{\beta}^{\text {restrict }}=\left[\begin{array}{lll}1 & -1 & -\gamma_{3} \text { timetrend }\end{array}\right]$ '. However, the estimates compare favourably with the ones obtained for the U.S. (Lustig and van Nieuwerburgh (2005)). In addition, the correlation between $h i_{t}$ obtained with the estimated and the restricted cointegration vector is 0.88 . Furthermore, the Lustig van Nieuwerburgh (2005) framework implies that consumption dispersion among households increases when $h i_{t}$ is temporarily low, i.e. when credit constraints are relatively tight as reaction to a relative reduction in collateral wealth. Then households find it difficult to insure against idiosyncratic shocks. Lustig and van Nieuwerburgh (2006a) show that these household constraints feed back to the regional level. The cross-sectional dispersion of regional consumption growth rates in the U.S. exhibits the same pattern as the variation in consumption across households. Hence, we should observe a similar pattern in Euro Area data. Figure (2) shows the cross-sectional standard deviation of Euro Area countries’ consumption growth rates together with its Hodrick-Prescott filtered trend and $h i_{t} \cdot{ }^{4}$ The visual inspection reveals the expected clear negative relation. Consumption dispersion is high in times of low housing-income ratio. Hence, the U.S. and the Euro Area seem to be very similar with respect to the statistical properties of their housing-toincome ratios. This finding is interesting by itself, since the institutional setups of housing markets differ remarkably in these two monetary unions (Tsatsaronis and Zhu (2004)).

\footnotetext{
${ }^{3}$ Here I use four leads and lags in the "dynamic" part of the OLS estimation. The estimates remain relatively stable from one to five leads and lags.

${ }^{4}$ Consumption data is taken form the latest issue of the IFS database. Growth rates are calculated from real, p.c. consumption in local currency. Consumption dispersion is the cross-sectional standard deviation of the euro area countries' consumption growth rates. The smoothing parameter in the HP filter is set to 1600 as I regard quarterly data.
} 


\subsection{The housing-income ratio and expected market risk premium}

According to Lustig and van Nieuwerburgh (2006b), $h i_{t}$ should predict risk premia on asset markets. This is also suggested by the housing consumption model of Piazzesi et al. (2007) in which the share of non-housing consumption in the consumption bundle is found to predict stock market returns. And indeed, Lustig and van Nieuwerburgh (2005) provide evidence for the predictive power of $h i_{t}$ for annual excess returns on U.S. stocks as a proxy for the market price of risk for the time span from 1926 to 2002. As Euro Area $h i_{t}$ reveals similar characteristics as its U.S. counterpart, $h i_{t}$ should be informative about the market price of risk in the Euro Area. In the Lustig and van Nieuwerburgh (2005, 2006b) model, temporarily high $h i_{t}$ is associated with less binding credit constraints so that the market risk premium is expected to decrease. Hence, we should observe negative slope coefficients in regressions of empirical proxies of the expected market risk premium on $h i_{t}$.

To gauge the plausibility of this argument, I run long-horizon regressions of the form:

$$
r_{t+h}^{i}=\alpha+\beta_{h}^{i} h i_{t}+\varepsilon_{t+h}
$$

with $r_{t+h}^{i}$, the logarithmic excess return on asset $i$ at time $t+h$ for the sample period from the first quarter of 1980 to the first quarter of 2007 both for the U.S. and the Euro Area. The forecast horizon $h$ is in quarters and $h i_{t}$ is the short-run variation in the housing-income ratio. Note also that $r_{t+h}^{i}=r_{t}^{i}+r_{t+1}^{i}+\ldots+r_{t+h-1}^{i}$.

As potential proxies for the return on the Euro Area and U.S. market portfolio I use the Dow Jones Euro Stoxx index as Euro Area stock index and Euro Area house price index changes as proxy for the real estate return. The latter series is again provided to me by the ECB. For the U.S., I use the MSCI country index and the residential real estate price index of the Bank for International Settlements (BIS) to obtain stock and real estate returns. I employ a 3-month money market rate of the Euro Area, which is a GDP weighted average of the Euro-12 
countries' short-term interest rates at 1999 PPP exchange rates, as the risk-free rate to obtain excess returns. The risk-free rate for the U.S. is the three-month treasury bill. I use the market value of residential real estate from the Z1 Flow of Funds Accounts of the FRB and after-tax labour income to calculate the U.S. version of $h i_{t}$. Data needed to obtain labour income is from the Bureau of Economic Analysis. The calculation of labour income follows the definition of Lettau and Ludvigson (2001).

Panel A of table 2 reports the results from the long-horizon regressions of potential market return proxies for the Euro Area and panel B of table 2 for the U.S. T-statistics in parenthesis are Newey-West corrected (Newey and West (1987)). As is evident from panel A, Euro Area $h i_{t}$ predicts both stock index and real estate returns at time horizons of 12 to 24 quarters. The evidence for the U.S. in panel B is slightly less significant but follows the same pattern as in the Euro Area. A temporarily high housing-income ratio predicts high returns on stock markets and low returns on real estate for the sample period from 1980Q1 to 2007Q1. Hence, against the backdrop of the Lustig and van Nieuwerburgh (2005) framework, these results suggest that rather the return on real estate than the return on a stock index should be used as an approximation of the market return. Given the institutional differences between the U.S. and the Euro Area highlighted in the introduction, this observation is puzzling. However, Lustig and van Nieuwerburgh (2005) show that in annual data and for a considerably longer time period, $h i_{t}$ normalized to take only positive values forecasts stock returns with the „right“ sign. ${ }^{5}$ Hence, the results for the U.S. seem to hinge on the particular sample period under study. Unfortunately, data for the Euro Area is not available for a longer time span and hence direct comparisons with the U.S. cannot be made in this respect. However, the implication for empirical tests of the CAPM is clear. Omitting the return on real estate in approximations of the market return does not seem to be innocuous. U.S. and Euro Area are

\footnotetext{
${ }^{5}$ Lustig and van Nieuwerburgh (2005) normalize short-run variations of the U.S. housing-income ratio such that it can only take positive values between 0 and 1 . Thus, they obtain the opposite signs compared with the not normalized housing-income ratio.
} 
strikingly similar in this respect. The next section assesses if this finding has practical relevance, i.e. if the real estate return really adds information about systematic risks in crosssectional asset pricing tests.

\section{The euro area market risk premium in the cross-section}

Based on the time-series evidence above, this section deals with the cross-sectional implications of the CAPM for average asset returns and assesses the role of the return on real estate wealth in particular.

\subsection{The CAPM and returns on real estate}

The capital asset pricing model of Sharpe (1964) and Lintner (1965) implies that any return on asset $\mathrm{i}, R^{i}$, in excess of the risk-free rate, $R^{f}$, is determined by its sensitivity to the risk premium on the market portfolio which comprises all risky assets, i.e.

$$
E\left(R^{i}\right)-R^{f}=\beta_{M}^{i}\left(E\left(R^{M}\right)-R^{f}\right)
$$

with $R^{M}$ the return on the market portfolio, $\beta_{M}^{i}=\frac{\operatorname{cov}\left(R^{i}, R^{M}\right)}{\operatorname{var}\left(R^{M}\right)}$ and $E($.$) denotes the$ expectation operator.

Typically, $R^{M}$ is approximated by returns on a broad stock market index, $R^{E Q}$. Returns on real estate, $R^{R E}$-- the focus of this study -- are usually neglected.

However, housing wealth is the dominant component of Euro Area households' asset wealth while equity plays a minor role in Euro Area households' balance sheets. Figure (1) displays the shares of equity and housing wealth in Euro Area households' asset wealth portfolio for the time period from the first quarter of 1980 to the first quarter of 2007. The share of housing is always around 60 percent of total asset wealth, while equity seems to be less important. In the course of the stock market surge in the late 1990s, the share of equity rises to about 20 percent of Euro Area households' asset wealth but declines subsequently. Furthermore, 
Norman et al. (2002) highlight that stock market participation in the core European countries is more limited than in the U.S. In 1997, 6.2\% of German and 12.0\% of French households participated in the stock market. In Italy $7.8 \%$ of households are engaged in the stock market while in the U.S. 19.2\% of households hold stocks in 1998.

While the role of real estate is less prominent in the U.S., the main findings of the previous section suggest that it is not clear a priori if the omission of real estate in tests of the CAPM are innocuous for the time period since the 1980s. Hence, this paper provides empirical evidence for the importance of returns on real estate in cross-sectional asset pricing both in the Euro Area and the U.S.

The cross-sectional empirical results of this paper are grounded in the stochastic discount factor representation of the most basic form of an asset pricing model, i.e.

$$
P_{t}^{i}=E_{t}\left[\beta \frac{u^{\prime}\left(C_{t+1}\right)}{u^{\prime}\left(C_{t}\right)} X_{t+1}^{i}\right]
$$

which arises naturally from the first-order conditions of an investor's utility maximization problem with $P_{t}^{i}$ the price of asset $i$ and $X_{t+1}^{i}$ the corresponding payoff. $E_{t}$ is the expectation operator conditional on time t information, $\beta$ is the subjective discount factor and $u^{\prime}(C)$ denotes the first derivative of the utility function $u(C) . C_{t}$ represents consumption at time t. Equivalently, gross returns, $\frac{X_{t+1}^{i}}{P_{t}^{i}}$, obey

$$
1=E_{t}\left(M_{t+1} R_{t+1}^{i}\right)
$$

with $M_{t+1} \equiv \beta \frac{u^{\prime}\left(C_{t+1}\right)}{u^{\prime}\left(C_{t}\right)}$ the stochastic discount factor (SDF) and $R_{t+1}^{i}$ the gross return on asset or portfolio $i$. Constantinides (1990) points out that all asset pricing models should proxy for the intertemporal marginal rate of substitution of consumption (IMRS), $\frac{u^{\prime}\left(C_{t+1}\right)}{u^{\prime}\left(C_{t}\right)}$. Therefore, the log-linear version of the SDF under consideration in this paper takes the form 


$$
m_{t+1}=a-b_{E Q} r_{t+1}^{e, E Q}-b_{R E} r_{t+1}^{e, R E}
$$

with the constant, $a$, the return on a broad stock market index in excess of the risk-free rate, $r_{t+1}^{e, E Q}$, and the return on real estate wealth in excess of the risk-free rate, $r_{t+1}^{e, R E}$. Here, I follow Kullmann (2001) and assume that the return on the market portfolio is linearly related to the returns on its components as I do not have exact information about the weights of stocks and real estate in the market portfolios of the Euro Area and the U.S.

This paper considers the log-linear version of equation (6) for excess returns

$$
0=E_{t}\left(m_{t+1} r_{t+1}^{e, i}\right)
$$

where lower-case letters denote logarithms and $r_{t+1}^{e, i}$ is the logarithmic return on asset $i$ over the risk-free rate.

Plugging (7) into (8), we obtain

$$
0=E_{t}\left(\left(a-b_{E Q} r_{t+1}^{e, E Q}-b_{R E} r_{t+1}^{e, R E}\right) r_{t+1}^{e, i}\right)
$$

which naturally suggests to assess the restrictions imposed by equation (9) on expected discounted asset returns in the generalized methods of moment (GMM) framework proposed by Hansen (1982). The GMM procedure then amounts to use pricing errors as moment conditions and choose the parameters of the SDF, the $b$ s, that relate the pricing factors with the asset returns such that the pricing errors are minimized.

Pricing errors for a given parameter vector, $b$, obey

$$
u_{t}(b)=\left(a-b_{E Q} r_{t+1}^{e, E Q}-b_{R E} r_{t+1}^{e, R E}\right) r_{t+1}^{e, i}
$$

Defining the sample mean of the pricing errors as $g_{T}(b)=\frac{1}{T} \sum_{t=1}^{T} u_{t}(b)$ with $T$ the number of time series observations, then the GMM estimation minimizes a quadratic form of pricing error sample means such that $\hat{b}=\arg \min \left(g_{T}(b)^{\prime} W g_{T}(b)\right)$ for the weighting matrix $W$. As I am particularly interested in the comparison of the performance of the CAPM with and without real estate, I follow Hansen and Jagannathan (1997) and use the covariance matrix of 
the test asset returns as weighting matrix in the GMM estimation. This approach has the advantage that this weighting matrix remains the same for all specifications of the CAPM and hence allows to compare the different CAPM versions directly via the Hansen-Jagannathan distance. The HJ-distance is also the maximum pricing error of the models under consideration (Hansen and Jagannathan (1997)). Dropping the time subscripts, the HJdistance is defined as

$$
H J-d i s t=\left[E(m r-0)^{\prime} E\left(r r^{\prime}\right)^{-1} E(m r-0)\right]^{1 / 2}
$$

with $r$, the vector of test asset returns and $m$, the logarithmic form of the SDF.

\subsection{Empirical results: Stock returns}

In the empirical implementation of the CAPM I use the stock indexes and returns on real estate from section 2.2. The test assets for the Euro Area are 12 value and growth portfolio returns. Value stocks, defined as stocks with high valuation ratio, e.g. with respect to their book value relative to market value, receive a lot of attention by practitioners as well as academics since Fama and French (1992) have shown that they offer higher average returns than expected from their market betas in standard capital asset pricing models such as the Sharpe (1964) and Lintner (1965) CAPM. This finding is not a unique observation on U.S. stock markets but by now well documented in international data (e.g. Chan et al. (1991), Capaul et al. (1995), Fama and French (1998)). Here, I assess differences in the performance of the three Euro Area CAPM versions (stock and real estate, stock only, real estate only) with regard to Euro Area countries’ value (high book-to-market ratio) and growth (low bookto-market ratio) stock portfolio returns. Kenneth French computes one value and one growth portfolio each for a variety of countries sorted by various valuation ratios. I employ value and growth portfolios of Belgium, France, Germany, Italy, Netherlands and Spain freely available 
from Kenneth French’s website. ${ }^{6}$ All returns under study are denominated in Euro or ECU, the precursor of the Euro. Pricing factors are demeaned.

The results are summarized in table 3, panel A. When stock and real estate return are considered to represent the market portfolio return jointly, the GMM estimates reveal that only the excess return on real estate helps to price the excess returns on the 12 Euro Area value and growth stock portfolios. Taking the stock market return alone, it does not seem to be helpful in explaining the cross-section of the value and growth stock returns in the Euro Area. The opposite observation can be made for the excess return on real estate as sole pricing factor. Note also that the HJ-distance, i.e. the maximum pricing error, is always lower for the CAPM variant with real estate. Hence, cross-sectional tests of the CAPM implications in the Euro Area that do not take real estate into account miss important information.

As panel B of table 3 shows, the opposite reasoning is true for the U.S. when confronted with the 25 book-to-market and size sorted Fama-French U.S. stock portfolio returns. Given the presence of each other, only the stock index return helps to price the Fama-French portfolios. Furthermore, the return on real estate does not help to track down the pricing errors. These results are very much in line with Stambaugh (1982) and hence underscore substantial differences between the Euro Area and the U.S. despite the remarkable similarity in terms of the implication of incomplete consumption risk sharing for the market return highlighted in section 2.2.

\subsection{Empirical Results: Excess returns on foreign currency portfolios}

The importance of different components of the market portfolio could differ across different classes of test assets (Stambaugh (1982)). This section focuses on excess returns on foreign currency portfolios as test assets for which the distinction between stock and real estate return in the market return could be particularly important.

\footnotetext{
${ }^{6}$ http://mba.tuck.dartmouth.edu/pages/faculty/ken.french/data library.html
} 
The presence of excess returns on foreign currencies is the direct evidence of the empirical failure of the uncovered interest rate parity condition. High interest rate currencies do not depreciate as much as expected from the difference between foreign and home interest rates and low interest rate currencies depreciate by more than expected from interest rate differentials (Fama (1984)). One possible explanation for this finding is that investors demand an extra risk premium for investments in foreign currencies (see e.g. the survey in Engle (1996)). If there is a risk premium in currency returns, then basic asset pricing theory should apply and explain cross-sectional differences in foreign currency returns. The first paper that provides an asset pricing based explanation is Lustig and Verdelhan (2007). After building portfolios of currencies according to their previous period's interest rate differential vis-à-vis the U.S., Lustig and Verdelhan (2007) show that a consumption-based asset pricing model explains the cross-sectional dispersion in foreign currency excess returns. High interest rate currencies tend to comove positively with U.S. aggregate consumption growth and thus have to compensate the U.S. investor with a risk premium. The opposite reasoning applies to low interest rate currencies. Interestingly, the Sharpe-Lintner CAPM seems to fail in this respect for the time period from 1953 - 2002. However, Lustig et al. (2008) show that the excess return on the U.S. stock market is priced in foreign currency returns in the time period from 1980 to 2008 but at the cost of an implausibly high risk price estimate.

Stock market indexes worldwide tend to move closely together which seems to mirror that national stock markets contain substantial global, common components (see e.g. Nitschka (2007) and the literature surveyed therein). Real estate price indexes are arguably less prone to global shocks as home owners build their houses where they live. Hence, a real estate return should reflect rather country-specific than global risks. The opposite reasoning seems to apply to stock returns.

In order to assess if there are material differences in the performance of the CAPM when confronted with foreign currency excess returns compared to the evidence presented in 
section two, I follow Lustig and Verdelhan (2007) and construct portfolios of quarterly foreign currency excess returns from the Euro Area and U.S. investor's point of view for the sample period from 1980Q1 to 2007Q1. Excess returns on foreign currencies are defined as $\varphi_{t+1}^{i}=i_{t}^{i}-i_{t}^{€}-\Delta e_{t+1}^{i}$ with $\Delta e_{t+1}^{i}$ the ECU/Euro (U.S. \$) exchange rate of country $i, i_{t}^{i}$ a shortterm interest rate (either 3-month money market rate or treasury bill) of country $i$ and $i_{t}^{€}$ the Euro Area (U.S.) short-term interest rate. Portfolio excess returns are arithmetic averages of the individual currency excess returns. Currencies are sorted into six bins according to their interest rate differential vis-à-vis the Euro Area/U.S. at time t. Portfolios are rebalanced every quarter where portfolio 1 contains the currencies from countries with lowest interest rate differential and portfolio 6 the countries with highest interest rate differentials. Countries from the Euro Area are excluded from the sample when building foreign currency portfolios from the Euro Area point of view but considered in the formation of foreign currency returns for the U.S. until the introduction of the Euro in 1999. The appendix provides more details on the construction of the portfolios and about the sample of countries.

Table 4 summarizes the descriptive statistics of the currency portfolios and provides annualized mean excess return, standard deviation and the corresponding Sharpe-ratio for the six interest rate differential sorted currency portfolios from the Euro Area (Panel A) and U.S. (Panel B) viewpoint. Consistent with the evidence presented in Lustig and Verdelhan (2007), low interest rate currencies provide low/negative excess returns while high interest rate currencies offer a high/positive risk premium. The currency risk premium is almost monotonically increasing with the interest rate differential.

Table 5 displays the GMM estimates for the various CAPM versions under study. Consistent with the evidence for stock returns, the real estate return helps to price foreign currency returns from the Euro Area perspective and lowers the pricing errors of the CAPM as Panel A of table 5 shows. The estimates presented in panel B of table 5 show the exactly opposite pattern for the U.S. CAPM. Here, the return on real estate neither helps to price the cross- 
section of foreign currencies nor improves the performance of the CAPM in terms of pricing errors.

Finally, I use the Fama-MacBeth cross-sectional regression (Fama and MacBeth (1973)) to assess if the return on one of the components of the market portfolio proxies under consideration is actually priced in foreign currency returns. The first stage of the FamaMacBeth estimation is a time series regression of excess returns on the currency portfolios on the market return proxies and a constant. The second step of the Fama-MacBeth regression consists of cross-sectional regressions of the currency excess returns on the estimated sensitivities to the market return (betas) at each point in time without a constant since we deal with excess returns. The resulting risk price estimates in percentage points per quarter are presented in table 6. Panel A provides the Euro Area and panel B the U.S. evidence. Tstatistics in parenthesis appear below the estimates and are corrected for the fact that the betas are generated regressors (Shanken (1992)). The column $\mathrm{R}^{2}$ gives the cross-sectional $\mathrm{R}^{2}$ adjusted for the number of regressors as used in Jagannathan and Wang (1996). The table also provides mean squared pricing errors (mspe) and mean absolute pricing errors (mape) in percentage points per quarter.

Apparently, the return on real estate is priced in foreign currency returns form the Euro Area perspective while the stock index return is not. The estimated risk price is about 2.2 percentage points per quarter. The Euro Area CAPM featuring real estate explains more than 50 percent of the cross-sectional variation in foreign currency returns. However, the pricing equation (8) could be applied to the respective pricing factor itself. A regression of the pricing factor on itself would give a regression coefficient of one, such that the mean excess return on that factor should equal its estimated risk price. Here, however, this condition is not fulfilled. The mean excess return of real estate in the Euro Area is about 0.5 percentage points per quarter. Hence, the estimated risk price is four times too large. The same reasoning applies to 
the significant risk price of the stock index excess return in the U.S. The estimated risk price is about 7.8 percent per quarter while the average excess return is 1.68 percent per quarter.

\section{Conclusions}

Real estate is typically neglected when the market portfolio of the Sharpe-Lintner CAPM is approximated. Based on the implications of incomplete consumption risk sharing for the return on the market portfolio, this paper shows that real estate should be considered in market return proxies of the Euro Area and the U.S. for the time period from the first quarter of 1980 to the first quarter of 2007. A relatively high amount of uninsured consumption risk should be associated with an expected increase in the market risk premium. This prediction of the Lustig and van Nieuwerburgh (2005) model considered in this paper is fulfilled for both the Euro Area and the U.S. if the return on real estate is used as market return proxy. However, despite this common observation in Euro Area and U.S. data, cross-sectional pricing tests of CAPM versions taking into account real estate document stark differences between the two.

The Euro Area market return seems to be more adequately approximated by the return on real estate than by the return on the Euro Area stock market. Irrespective if stock excess returns or excess returns on foreign currencies are considered, a CAPM version featuring the return on real estate always delivers the lowest pricing errors. In addition, given the presence of each other, it is the return on real estate that helps to price asset returns not the stock index return. The opposite reasoning applies to the U.S.

Taken together these findings suggest that tests of the Euro Area CAPM miss important information when real estate is neglected in empirical proxies of the market portfolio. The common practice to use stock market returns as stand-in for the market return seems to be innocuous for the U.S. but not for the Euro Area. In addition, the main results of this paper suggest that the distinction between rather global and country-specific pricing factors, i.e. 
stock index vs. real estate return, does not have an important impact on the pricing of foreign currency excess returns. 


\section{Appendix}

\section{Construction of currency portfolios}

Following Lustig and Verdelhan (2007) I construct portfolios of quarterly currency excess returns from the perspective of a Euro Area and U.S. investor. Excess returns on foreign currencies are defined as $\varphi_{t+1}^{i}=i_{t}^{i}-i_{t}^{€}-\Delta e_{t+1}^{i}$ with $\Delta e_{t+1}^{i}$ the ECU/Euro (U.S. \$) exchange rate of country $i, i_{t}^{i}$ a short-term interest rate (either 3-month money market rate or treasury bill) of country $i$ and $i_{t}^{€}$ the Euro Area (U.S.) short-term interest rate. Portfolio excess returns are arithmetic averages of the individual currency excess returns. Currencies are sorted into bins according to their interest rate differential vis-à-vis the euro area, i.e. $i_{t}^{i}-i_{t}^{\epsilon}$. Portfolios are rebalanced every quarter where portfolio 1 contains the currencies from countries with lowest interest rate differential vis-à-vis the euro area and portfolio 6 the countries with highest interest rate differentials. The sample period runs from the first quarter of 1980 to the first quarter of 2007. Since data on exchange rates and short-term interest rates is not available for all of the countries under study over the whole sample period, the number of countries included in the portfolios varies over time. The countries under consideration are Australia, Canada, Chile, China, Colombia, Czech Republic, Denmark, Egypt, Hong Kong, Hungary, India, Indonesia, Israel, Japan, Jordan, Korea, Malaysia, Mexico, Morocco, New Zealand, Norway, Pakistan, Peru, Philippines, Poland, Russia, Singapore, South Africa, Sri Lanka, Sweden, Switzerland, Thailand, Turkey, UK, USA and Venezuela.. Short-term interest rates and nominal ECU/Euro as well as Dollar exchange rates are obtained from the IMF Financial Statistics as well as from the ECB.

I additionally include the following Euro Area countries until the introduction of the Euro in January 1999 in the formation of foreign currency portfolios from the U.S. investors perspective: Austria, Belgium, Finland, France, Germany, Greece, Ireland, Italy, Netherlands, Portugal and Spain. 


\section{References}

Artis, Michael J. and Mathias Hoffmann (2007), “The Home Bias and Capital Income Flows between Countries and Regions”, IEW working paper 316, University of Zurich

Asdrubali, Pierfederico, Bent E. Sørensen and Oved Yosha (1996), "Channels of Interstate Risk Sharing: the United States 1963-1990”, Quarterly Journal of Economics 111, 10811110.

Bansal, Ravi and Magnus Dahlquist (2000), "The Forward Premium Puzzle: Different Tales from Developed and Emerging Markets", Journal of International Economics 51(1), 115-144.

Black, Fischer (1972), “Capital market equilibrium with restricted borrowing”, Journal of Business 45, 444-455.

Campbell, John Y. (1996), “Understanding Risk and Return”, Journal of Political Economy 104, 298-345.

Capaul, Carlo, Ian Rowleya and William F. Sharpe (1993), "International value and growth stock returns”, Financial Analysts Journal, 27-36.

Chan, Louis K.C., Yasushi Hamao and Josef Lakonishok (1991), "Fundamentals and stock returns in Japan”, Journal of Finance 46, 1739-1789.

Constantinides, George M. (1990), "Habit Formation: A Resolution of the Equity Premium Puzzle”, Journal of Political Economy 98, 519-543.

Engel, Charles (1996), "The forward discount anomaly and the risk premium: A survey of recent evidence", Journal of Empirical Finance, 3, 123-192.

Engle, Robert F. and Clive W.J. Granger (1987), "Co-Integration And Error Correction: Representation, Estimation and Testing”, Econometrica 55, 251-276.

European Central Bank (2006), ECB monthly bulletin, December 2006

Fama, Eugene F. (1984), "Forward and Spot Exchange Rates", Journal of Monetary Economics, 14, 319-338.

Fama, Eugene F. and James D. MacBeth (1973), "Risk, Return and Equilibrium: Empirical Tests", Journal of Political Economy, 81, 607-631.

Fama, Eugene F. and Kenneth R. French (1992), “The Cross-Section of Expected Stock Returns”, Journal of Finance 47, 427-465.

Fama, Eugene F. and Kenneth R. French (1998), "Value versus Growth: The International Evidence”, Journal of Finance 53, 1975-1999.

Gertler, Mark and Simon Gilchrist (1994), „Monetary Policy, Business Cycles, and the Behaviour of Small Manufacturing Firms”, Quarterly Journal of Economics 109, 309-340. 
Hamburg, Britta, Mathias Hoffmann and Joachim Keller (2007), "Consumption, Wealth and Business Cycles: Why is Germany different?” forthcoming Empirical Economics

Hansen, Lars Peter (1982), "Large sample properties of Generalized Method of Moments estimators”, Econometrica 50, 1029-1054.

Hansen, Lars Peter and Ravi Jagannathan (1997), “Assessing specification errors in stochastic discount factor models”, Journal of Finance 52, 557-590.

Jagannathan, Ravi and Zhengyu Wang (1996), "The Conditional CCAPM and the CrossSection of Expected Returns”, Journal of Finance 51, 3-53.

Kullmann, Cornelia (2001), “Real Estate and its Role in Asset Pricing”, unpublished working paper , Columbia University

Lintner, John (1965), "The valuation of risk assets and the selection of risky investments in stock portfolios and capital budgets", Review of Economics and Statistics ,47, 13-37.

Lustig, Hanno and Stijn van Nieuwerburgh (2005), „Housing Collateral, Consumption Insurance and Risk Premia”, Journal of Finance 60, 1167-1219.

Lustig, Hanno and Stijn van Nieuwerburgh (2006a), „How much does Household Collateral constrain Regional Risk Sharing?”, working paper UCLA and NYU Stern

Lustig, Hanno and Stijn van Nieuwerburgh (2006b), „Can Housing Collateral explain LongRun Swings in Asset Returns?”, working paper UCLA and NYU Stern

Lustig, Hanno, Nick Roussanov and Adrien Verdelhan (2008), "Common Risk Factors in Currency Markets”, working paper UCLA, Wharton School, Boston University.

Lustig, Hanno and Adrien Verdelhan (2007), “The Cross-Section of Foreign Currency Risk Premia and Consumption Growth Risk”, American Economic Review 97, 89-117.

Newey Whitney K. and Kenneth D. West (1987), “A simple, positive semidefinite, heteroskedasticity and autocorrelation consistent covariance matrix", Econometrica 55, 703708.

Nitschka, Thomas, (2007), "International evidence for return predictability and its implications for the long-run covariation of the G7 stock markets”, IEW working paper 338, University of Zurich

Norman, Ben, Maria Sebastia-Barriel and Olaf Weeken (2002), "Equity wealth and consumption - the experience of Germany, France and Italy in an international context”, Bank of England Quarterly Bulletin Spring 2002.

Piazzesi, Monika, Martin Schneider and Selale Tuzel (2007), „Housing, consumption, and asset pricing”, Journal of Financial Economics 83, 531-569.

Shanken, Jay (1992), “On the estimation of beta-pricing models”, Review of Financial Studies $5,1-33$ 
Sharpe, William F. (1964), "Capital asset prices: A theory of market equilibrium under conditions of risk", Journal of Finance 19, 425-442.

Sørensen, Bent E. and Oved Yosha (1996), "International Risk Sharing and European Monetary Unification”, Journal of International Economics 45, 211-238.

Stambaugh, Robert F. (1982), "On the Exclusion of Assets from Tests of the Two-Parameter Model: A Sensitivity Analysis”, Journal of Financial Economics 10, 237-268.

Tsatsaronis, Kostas and Haibin Zhu (2004), „What drives housing price dynamics: crosscountry evidence” BIS Quarterly Review 


\section{Tables}

Table 1: Johansen Cointegration Test

\begin{tabular}{lll}
\hline \hline & $\underline{\text { Trace }}$ & $\underline{\text { L-Max }}$ \\
$\mathrm{r}=0$ & $24.83^{* * *}$ & $22.72 * * *$ \\
$\mathrm{r}=1$ & 2.11 & 2.11
\end{tabular}

Notes: This table presents test statistics of the Johansen cointegration test allowing for a time trend and two lags as suggested by standard information criteria. The Trace test tests the null of $r$ cointegrating relationships against the alternative of $p$, the number of variables in the tested system, cointegrating relations. The L-Max test tests the null of $r$ cointegrating relations against the alternative of $\mathrm{r}+1$. $*$ denotes significance at $90 \%$, ** at $95 \%$ and $* * *$ at $99 \%$ level. The variables under consideration are housing wealth and disposable income of Euro Area households. Both of the series are quarterly and expressed in natural logarithms as well as in real and per capita terms. The sample spans the period from the first quarter of 1980 to the first quarter of 2007. 
Table 2: Long-horizon regressions of excess returns on stocks and real estate

\begin{tabular}{|c|c|c|c|c|c|c|c|}
\hline \multicolumn{8}{|c|}{ Panel A: Euro Area } \\
\hline & $h=1$ & $h=4$ & $H=8$ & $h=12$ & $h=16$ & $h=20$ & $h=24$ \\
\hline Stocks & $\begin{array}{l}0.11 \\
(1.03)\end{array}$ & $\begin{array}{l}0.53 \\
(1.14)\end{array}$ & $\begin{array}{l}1.55 \\
(1.54)\end{array}$ & $\begin{array}{l}2.94 * \\
(2.42)\end{array}$ & $\begin{array}{l}4.01 * \\
(3.95)\end{array}$ & $\begin{array}{l}4.87 * \\
(7.19)\end{array}$ & $\begin{array}{l}5.29 * \\
(7.12)\end{array}$ \\
\hline$R^{2}$ & 0.00 & 0.03 & 0.11 & 0.24 & 0.34 & 0.42 & 0.53 \\
\hline real estate & $-{ }_{(-1.13)}^{0.02}$ & $-\underset{(-1.39)}{0.12}$ & $\underset{(-1.93)}{-0.36}$ & $\underset{(-2.54)}{-0.67} *$ & $\underset{(-3.20)}{-0.97} *$ & $\frac{-1.06}{(-3.40)}$ & $\underset{(-2.93)}{-0.95}$ * \\
\hline$R^{2}$ & 0.01 & 0.06 & 0.15 & 0.24 & 0.33 & 0.30 & 0.20 \\
\hline
\end{tabular}

Panel B: U.S.

\begin{tabular}{cccccccc}
\hline Stocks & $\underset{(0.12)}{0.01}$ & $\underset{(-0.07)}{-0.02}$ & $\underset{(0.09)}{0.08}$ & $\underset{(0.35)}{0.48}$ & $\underset{(0.77)}{1.29}$ & $\underset{(1.03)}{1.92}$ & $\underset{(1.30)}{2.52}$ \\
$R^{2}$ & -0.01 & -0.01 & -0.01 & -0.00 & 0.04 & 0.07 & 0.14 \\
\hline real estate & $\underset{(0.08)}{0.00}$ & $\underset{(-0.20)}{-0.02}$ & $\underset{(-0.74)}{-0.15}$ & $\underset{(-1.83)}{-0.42}$ & $\underset{(-3.25)}{-0.73 *}$ & $\underset{(-4.62)}{-0.99 *}$ & $\underset{(-6.19)}{-1.23 *}$ \\
$R^{2}$ & -0.01 & -0.01 & 0.02 & 0.12 & 0.28 & 0.44 & 0.58
\end{tabular}

Notes: This table reports estimates from long-horizon regressions of the form:

$$
x_{t+h}=\alpha+\beta^{h} h i_{t}+\varepsilon_{t+h}
$$

where $x$ denotes either the excess return on a stock index or real estate return in excess of the risk-free rate for the Euro Area and the U.S. at time horizon $t+h$. The regressor, $h i_{t}$, is the temporary deviation from the long-term trend in the ratio of residential housing wealth and disposable income in the Euro Area or residential real estate wealth and after-tax labour income in the U.S.. The forecast horizon, $h$, is in quarters. The t-statistics are Newey-West corrected (Newey and West (1987)) and appear below the regressor estimates in parenthesis. The row below the estimates reports the adjusted $R^{2}$ statistic. Asterisk indicates significance at the $95 \%$ confidence level. The sample spans the period from the first quarter of 1980 to the first quarter of 2007. 
Table 3: GMM estimates (value and growth stocks)

\begin{tabular}{|c|c|c|c|}
\hline \multicolumn{4}{|c|}{ Panel A: Euro Area } \\
\hline & $b_{E Q}$ & $b_{R E}$ & HJ-Distance \\
\hline $\begin{array}{l}\text { CAPM (stock and } \\
\text { real estate }\end{array}$ & $\begin{array}{l}1.67 \\
(0.70)\end{array}$ & $-\underset{(-2.20)}{21.59} *$ & 0.3121 \\
\hline CAPM (stock) & $\begin{array}{l}2.07 \\
(1.07)\end{array}$ & & 0.3475 \\
\hline CAPM (real estate) & & $-\underset{(-2.43)}{24.92} *$ & 0.3240 \\
\hline \multicolumn{4}{|c|}{ Panel B: U.S. } \\
\hline & $b_{E Q}$ & $b_{R E}$ & HJ-Distance \\
\hline $\begin{array}{l}\text { CAPM (stock and } \\
\text { real estate }\end{array}$ & $\underset{(1.99)}{2.81} *$ & $-\underset{(-1.43)}{22.83}$ & 0.7457 \\
\hline CAPM (stock) & $\underset{(1.97)}{2.62} *$ & & 0.7674 \\
\hline CAPM (real estate) & & $-\underset{(-1.29)}{20.07}$ & 0.7806 \\
\hline
\end{tabular}

Notes: This table shows parameter estimates, $b_{E Q}$ and $b_{R E}$, from a GMM estimation of the CAPM confronted with stock portfolio returns. The weighting matrix is the covariance matrix of the test asset returns in order to compute the Hansen-Jagannathan distance (Hansen and Jagannathan (1997)) which mirrors the maximum pricing error of the model. Panel A presents the estimates for the Euro Area where 12 Euro Area countries' value and growth stock portfolio returns are used as test assets. Panel B displays the respective estimates for the U.S. when the CAPM is employed to explain the cross-section of the 25 book-to-market and size sorted Fama-French portfolios. T-statistics of the estimates appear below the estimates in parenthesis. The market portfolio excess return is proxied by the excess return on a stock market index and on real estate (CAPM (stock and real estate)) or the stock market return (CAPM (stock)) or the excess return on real estate (CAPM (real estate)). Asterisk indicates significant estimates at the 95\% confidence level 
Table 4: Descriptive Statistics of foreign currency excess returns

\begin{tabular}{lllllll}
\hline \hline & \multicolumn{5}{c}{ Panel A: Euro Area } \\
\hline $\begin{array}{l}\text { mean } \\
\text { return }\end{array}$ & -4.12 & -2.65 & 0.65 & -2.37 & 0.47 & 2.61 \\
\hline $\begin{array}{l}\text { Standard } \\
\text { deviation }\end{array}$ & 15.68 & 16.46 & 15.88 & 18.44 & 18.97 & 24.68 \\
\hline $\begin{array}{l}\text { Sharpe } \\
\text { Ratio }\end{array}$ & -0.27 & -0.16 & 0.04 & -0.13 & 0.03 & 0.11 \\
\hline & & & & & & \\
\hline & 1 (Low) & 2 & 3 & 4 & 5 & 6 (High) \\
\hline $\begin{array}{l}\text { mean } \\
\text { return }\end{array}$ & -2.91 & 0.02 & 1.42 & -0.30 & 0.98 & 4.17 \\
\hline $\begin{array}{l}\text { Standard } \\
\text { deviation }\end{array}$ & 15.55 & 17.06 & 15.13 & 14.43 & 14.88 & 17.78 \\
\hline $\begin{array}{l}\text { Sharpe } \\
\text { Ratio }\end{array}$ & -0.19 & 0.00 & 0.09 & -0.02 & 0.07 & 0.23 \\
& & & & & &
\end{tabular}

Notes: Panel A provides annualized mean returns, standard deviations and the Sharpe ratio for excess returns on foreign currencies sorted into portfolios according to the respective interest rate differential with the Euro Area. The sample period spans the time from first quarter of 1980 to the first quarter of 2007. Excess returns on foreign currencies are defined as $\varphi_{t+1}^{i}=i_{t}^{i}-i_{t}^{€}-\Delta e_{t+1}^{i}$ with $\Delta e_{t+1}^{i}$ the ECU/Euro exchange rate of country $i, i_{t}^{i}$ a short-term interest rate (either 3-month money market rate or treasury bill) of country $i$ and $i_{t}^{\epsilon}$ the euro area short-term interest rate. Portfolio excess returns are arithmetic averages of the individual currency excess returns. Portfolios are rebalanced every quarter where portfolio 1 contains the currencies from countries with lowest interest rate differential vis-à-vis the euro area and portfolio 6 the countries with highest interest rate differentials. The appendix gives more detailed information about the currency portfolio formation and countries included in the sample.

Panel B gives the characteristics of foreign currency portfolios from the U.S. investors perspective. 
Table 5: GMM estimates (excess returns on portfolios of foreign currencies)

\begin{tabular}{|c|c|c|c|}
\hline \multicolumn{4}{|c|}{ Panel A: Euro Area } \\
\hline & $b_{E Q}$ & $b_{R E}$ & HJ-Distance \\
\hline $\begin{array}{l}\text { CAPM (stock and } \\
\text { real estate }\end{array}$ & $\begin{array}{l}-0.87 \\
(-0.22)\end{array}$ & $\begin{array}{l}-66.38 \\
(-1.74)\end{array}$ & 0.4627 \\
\hline CAPM (stock) & $\begin{array}{c}-3.40 \\
(-0.76)\end{array}$ & & 0.4921 \\
\hline CAPM (real estate) & & $-\underset{(-1.97)}{69.63 *}$ & 0.4632 \\
\hline \multicolumn{4}{|c|}{ Panel B: U.S. } \\
\hline & $b_{E Q}$ & $b_{R E}$ & HJ-Distance \\
\hline $\begin{array}{l}\text { CAPM (stock and } \\
\text { real estate }\end{array}$ & $\underset{(2.35)}{9.53} *$ & $-\underset{(-0.74)}{27.62}$ & 0.3491 \\
\hline CAPM (stock) & $\underset{(2.70)}{8.36} *$ & & 0.3631 \\
\hline CAPM (real estate) & & $-\underset{(-0.07)}{2.22}$ & 0.4435 \\
\hline
\end{tabular}

Notes: This table shows parameter estimates, $b_{E Q}$ and $b_{R E}$ from a GMM estimation of the CAPM confronted with excess returns on foreign currencies from the Euro Area as well as U.S. investor's perspective. The weighting matrix is the covariance matrix of the test asset returns in order to compute the Hansen-Jagannathan distance (Hansen and Jagannathan (1997)) which mirrors the maximum pricing error of the model. Panel A presents the estimates for the Euro Area. Panel B displays the respective estimates for the U.S. T-statistics of the estimates appear below the estimates in parenthesis. The market portfolio excess return is proxied by the excess return on a stock market index and on real estate (CAPM (stock and real estate)) or the stock market return (CAPM (Stock)) or the excess return on real estate (CAPM (real estate)). Asterisk indicates significant estimates at the 95\% confidence level 
Table 6: Risk price estimates from CAPM

for excess returns on foreign currency portfolios

\begin{tabular}{cccccc}
\hline \hline \multicolumn{5}{c}{ Panel A: Euro Area } \\
\hline & $\lambda_{E Q}$ & $\lambda_{R E}$ & $R^{2}$ & mspe & mape \\
\hline $\begin{array}{c}\text { Fama } \\
\text { MacBeth }\end{array}$ & -0.02 & 2.23 & 0.56 & 0.14 & 0.32 \\
\hline \multicolumn{1}{c}{$(-0.01)$} & ${ }^{(3.43)}$ & & & \\
\hline & $\lambda_{E Q}$ & $\lambda_{R E}$ & $R^{2}$ & mspe & mape \\
\hline Fama & 7.79 & -0.15 & 0.68 & 0.09 & 0.29 \\
MacBeth & $(3.03)$ & $(-0.37)$ & & & \\
\hline
\end{tabular}

Notes: This table presents risk price estimates from Fama-MacBeth cross-sectional regressions on Euro Area (Panel A) and U.S. (Panel B) CAPM versions where the market return is proxied by the return on a stock index and the return on real estate.

The first stage of the Fama-MacBeth estimation is a time series regression of excess returns on currency portfolio $j, \varphi_{t}^{j}$, on the pricing factors, i.e.

$$
\varphi_{t}^{j}=\mu+\beta_{E Q}^{j} r_{t}^{e, E Q}+\beta_{R E}^{j} r_{t}^{e, R E}+\varepsilon_{t}^{j}
$$

with $r_{t}^{q, E Q}$ the return on the Euro Area or U.S. stock index in excess of the risk-free rate and $r_{t}^{q, R E}$ the return on the Euro Area or U.S. residential house price index in excess of the riskfree rate.

The second stage of the Fama-MacBeth regression amounts to cross-sectional regressions at each point in time, i.e.

$$
\varphi_{t}^{j}=\lambda_{E Q} \hat{\beta}_{E Q}^{j}+\lambda_{R E} \hat{\beta}_{R E}^{j}+v_{t}^{j}, \forall t
$$

The point estimates of the risk prices, $\lambda_{\Delta c}$ and $\lambda_{R E}$, are reported in percentage points per quarter. T-statistics in parenthesis appear below the estimates and are corrected for the fact that the betas are generated regressors (Shanken (1992)). The column $\mathrm{R}^{2}$ gives the crosssectional $\mathrm{R}^{2}$ adjusted for the number of regressors as used in Jagannathan and Wang (1996). The table also provides mean squared pricing errors (mspe) and mean absolute pricing errors (mape) in percentage points per quarter. 


\section{Figures}

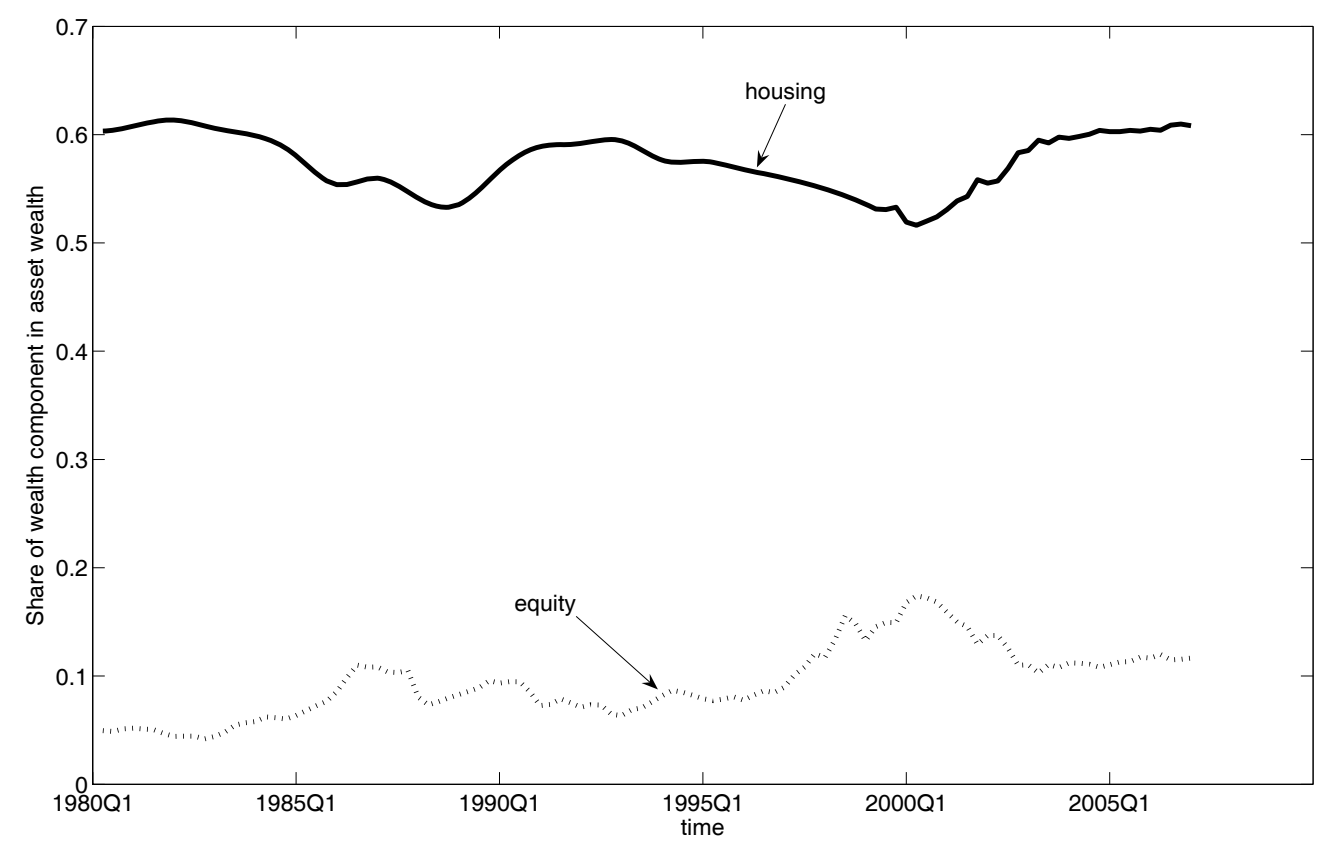

Figure 1: Share of housing wealth and equity in Euro Area households' asset wealth for the time period from 1980Q1 to 2007Q1

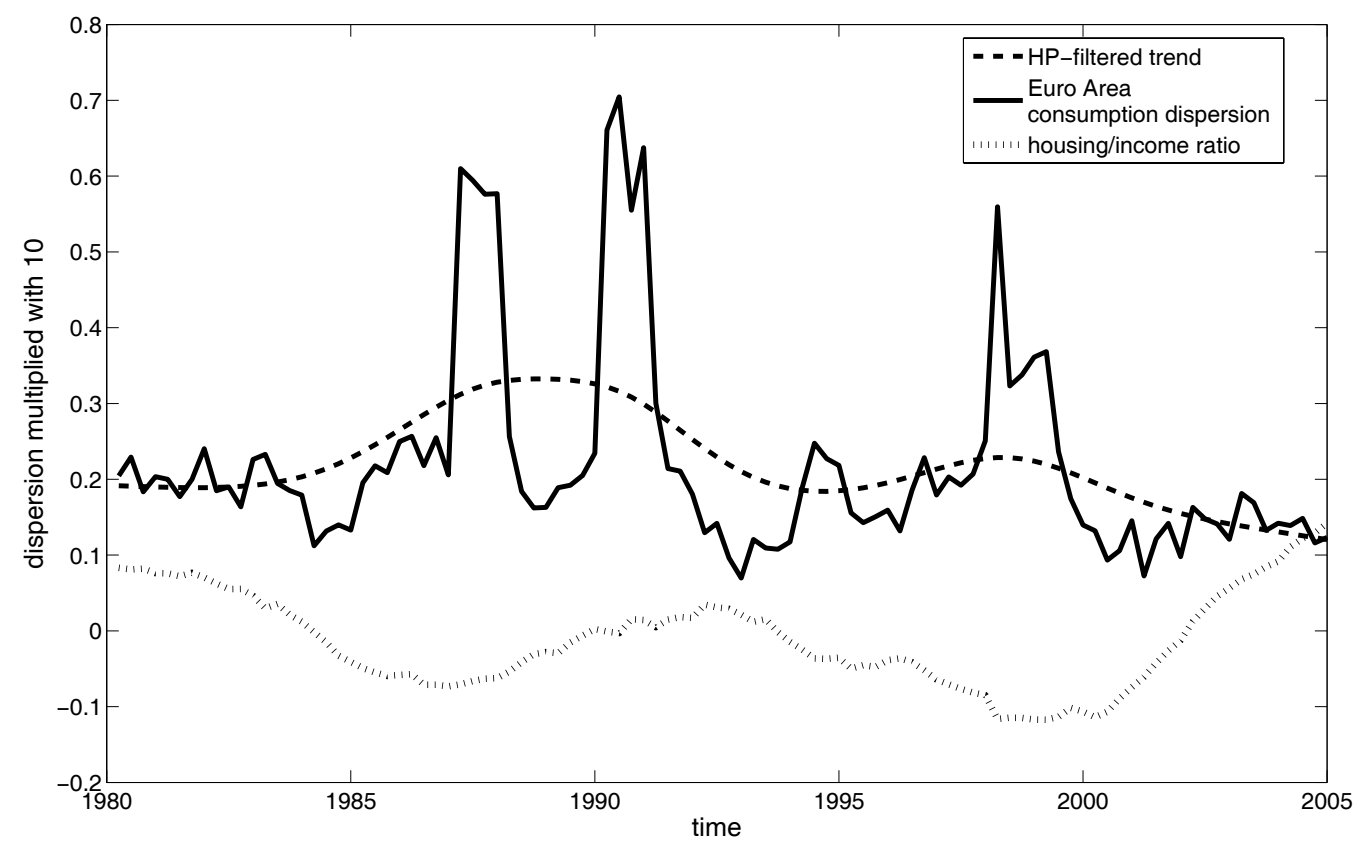

Figure 2: Short-run variation in housing-income ratio and cross-sectional dispersion in EMU countries' consumption growth rates 